\title{
THE BRITISH-IRISH BORDER IN THE CONTEXT OF BREXIT
}

The existence of national borders stems primarily from the attribution of territory to states and from the territoriality instinct inherent in human communities. A state border, determining the geographical location of a territory, defines not only the area of a state, but also performs certain functions which are essentially internal and external in nature.

The internal dimension of a state border is determined by the spatial extent of the territorial sovereignty of authorities and, in this respect, concerns the regulations and freedom of action of various groups within a state, migration, as well as financial and material transfers and the flow of information outside the territory. Thus, a border, in this context, determines the space within which a state performs the functions ensuing from its authority.

The internal dimension of a border, on the other hand, concerns restricted access to a state's territory by all entities operating outside its territory.

Since the 1990s, an increased interest in borders and the functioning of border areas has been observed in various scientific disciplines. This may be related to the fact that since then we have witnessed the process of transformation of the geographical and political space. On the one hand, these tendencies have been caused by changes in the political map of the world, related to the break-up of some countries (for example, the USSR, Yugoslavia, Czechoslovakia or Sudan), or the emergence of new independent political entities (for example, East Timor or Kosovo). It can also be noted that the reason for these phenomena is the evolution of the functions of a state border in the conditions of integration processes taking place in both supranational and transnational dimensions.

With the development of integration processes, the traditional functions of state borders related to the protection of territoriality and sovereignty have been taken over by the borders of integration groups (Trzcielińska-Polus, 2010: 161). Within integration groups, two types of borders have been formed:

- internal borders, referred to as soft borders, where the barrier function and the related restrictions are most often limited, which is the consequence of the adopted policy of liberalism,

- external borders, referred to as hard borders, where the function of a border as a barrier is strengthened, which in turn corresponds to the principles of the policy of protectionism (Grochalski, 2010: 27).

In Europe, the process of the development of internal and external borders is the most evident. This is due to the integration processes taking place in the area for many 
years, which refer to the blending of the influences of the numerous structures developed by the countries on the continent. The European Union is an integration structure of countries within which the division into internal and external borders has become the most visible. On the one hand, it represents the highest level of economic integration (an economic and monetary union) and, on the other hand, it is an expression of the establishment of institutional conditions for the citizens of Member States to exercise their right to travel freely, work, study or reside in a chosen country of the area. This freedom of movement is linked to the disappearance of the functions of internal borders seen as barriers (Balawajder, 2017: 201-202).

Until the time of formalizing the UK's exit from the European Union, the organization had been developing by increasing the number of Member States (integration "to the outside") and by deepening cooperation (integration "to the inside"). The effect of these changes was an evolution of the border function within the European Union, related to the abandoning of the barrier dimension at the internal borders and at the same time strengthening this dimension in relation to the external borders (Balawajder, 2010: 114-119).

As soon as the United Kingdom leaves the European Union (an event known in journalism as "Brexit"), a significant qualitative change in the process of this evolution will take place. For the first time an internal border of the Union becomes its external border.

The aim of the paper is to analyse the problem of the functioning of the British-Irish border after the so-called Brexit (the author would like to emphasize that "Brexit" is a journalistic rather than scientific term, however, the use of this term facilitates this analysis). The problem of Brexit concerns not only the change of the previous trade relations between the UK and the European Union, but also poses a significant challenge related to the issue of the British-Irish border, which is perceived as not only a border line between the two countries, but also an external border of the European Union.

The author puts forward the following hypothesis: the fact that the United Kingdom leaves the European Union means that an optimal solution has to be found to enable the United Kingdom both to correlate its economy with the Union and to set such a dimension of the Irish-British border that, with the border being the external border of the Union, the maximum possible abolishment of restrictions when crossing it would be ensured.

The main research question posed by the author is the following: what is the possible model of mutual relations and the related dimension of the border as a barrier? Currently, in the signed Agreement, only the legal framework for future relations between the United Kingdom and the Union and between the Republic of Ireland and Northern Ireland has been formalized (Agreement on the, 2020: 7-187). The transitional period lasting until 2022 will determine the final shape of the relationship and will affect the actual nature of the border between the United Kingdom and the European Union. Using mainly the descriptive and empirical method, the author puts forward the thesis that if the negotiations cause a significant loosening of relations between the United Kingdom and the European Union, in order to mitigate the effects of this situation on the Irish-British relations, it will be necessary to find and develop bilateral solutions facilitating the crossing of the border. The Smart Border 2.0 concept may constitute such a solution. 
Currently, the British-European Union border comprises several sections. This is, for example, the land border between Gibraltar and Spain, or the border between the Sovereign Base Areas (SBA) in Cyprus and the Republic of Cyprus. However, the most important is the British-Irish border on the island of Ireland. This border, $499 \mathrm{~km}$ long, was established in 1921 pursuant to the Anglo-Irish Treaty, under which twentysix Catholic counties were granted autonomy (The text, 2019). At the same time, the six northern counties, mostly inhabited by the Protestant majority, remained within the United Kingdom as Northern Ireland, which determined the division of the island. The line of this division was therefore the border between the Republic of Ireland and Ulster, which in the minds of the Irish was an imposed border separating them on both sides of the island (Anderson, 2004: 52). This sense of separation by the border was reinforced by the events of 1949, when, as a result of Ireland's withdrawal from the Commonwealth of Nations and the enactment of the Irish Act, which included a provision that the Republic of Ireland was no longer part of the United Kingdom (the Ireland Act, 1949), all political and legal links between the United Kingdom and Ireland were severed. However, the Irish people's awareness of living on both sides of the border meant that what was involved in formal British-Irish relations did not reduce those relations completely, particularly at the border with Ulster. Irish citizens continued to have the right of unrestricted entry into the United Kingdom, and could automatically apply for British citizenship if they wanted to live in the UK. Social, cultural, sports, and professional relations were developing, both between the two parts of Ireland and between them and the other parts of the UK (Whyte, 1983).

Despite the development of relations between Great Britain and the two parts of Ireland, the existence of a border within the island strengthened the division of Northern Ireland into two isolated communities differing in terms of religion, tradition, level of education, sense of state and national affiliation, and historical memory (Whyte, 1991).

The division of the island and discrimination against the Catholic population led in 1968 to a conflict that lasted until 1998 and had all the attributes of a civil war. The conflict in Northern Ireland gave a special character to this part of the island and strengthened the perception of the Irish-Ulster border as a particular barrier separating the stable Republic of Ireland from the unstable Ulster.

With the accession of the Republic of Ireland and the United Kingdom to the European Communities in 1973, an evolution in the perception of this border could be observed: it was gradually losing its character of a barrier. This border initially became the internal border of the European Economic Community and, following the entry into force of the Maastricht Treaty, the internal border of the European Union, with all the consequences for the free movement of persons, goods, capital and services.

\section{THE ESSENCE OF THE IRISH-BRITISH BORDER}

It can therefore be concluded that, under the current conditions, after the formalization of Brexit, the status of the Irish-British border is determined by the following factors: 
1) the former membership of the United Kingdom and the lasting membership of the Republic of Ireland in the European Union,

2) the Good Friday Agreement of 1998 ,

3 ) the functioning of both countries in the Common Travel Area (CTA).

Under the conditions of the membership of the United Kingdom and the Republic of Ireland in the European Union, this border disappeared as a barrier in economic and customs-related terms. The full implementation of the four freedoms became possible with the establishment of the European Single Market in 1992. Before that time, from 1923 onwards, customs control had been carried out at the border (Smart Border 2.0, 2017: 9). The free movement of people, goods, capital and services resulted in a mutual trade volume of almost $€ 3$ billion. Every day, going to work, about thirty thousand residents of the border zone crossed the state line in both directions in 275 places (Inter Trade Ireland, 2017). Thus, it can be said that in economic and customs-related terms, this border was unnoticeable. The only indications of the border were road signs informing that when entering Northern Ireland, the speed limit is given in miles rather than kilometres per hour. There were also two different monetary systems: the euro area and the pound area.

The Good Friday Agreement of 1998 caused a gradual disappearance of this border, in terms of both national politics and national identity. Above all, after the agreement, the identities of the inhabitants of Northern Ireland, the Republic of Ireland and the United Kingdom no longer constituted such sharp and problematic dividing lines. One of the most important achievements of the agreement was the creation of a new criterion of national affiliation. This document sanctioned the birth right of every inhabitant of Northern Ireland to accept British citizenship, Irish citizenship or both (Ireland in brief Dublin, 2000: 49; Crawley, 2019).

The Common Travel Area (CTA) is an open border area covering Great Britain, including the Channel Islands, the Isle of Man, and Ireland. Under the CTA, Irish and British citizens have the right to travel freely with a minimum scope of border controls in specific cases related to crime combating. The CTA also grants special status to Irish citizens residing in the United Kingdom and to British citizens residing in the Republic of Ireland (Common Travel Area, 2019).

The Common Travel Area has existed since 1923 and is connected with the establishment of the Irish Free State. Thus, due to the CTA, a free travel area had been established before both countries joined the European Economic Community, and in the pre-accession period, a zone resembling to a passport union was created. The Common Travel Area was suspended in 1939 and reinstated in 1952.

At the time when the Amsterdam Treaty went into force (1999), the Protocol of the incorporation of the Schengen acquis into the main body of the European Union law confirmed that the United Kingdom and Ireland were not bound by the provisions of the Schengen Agreement (Wojtaszek-Mik, Mik, 2005: 339-340). In turn, in the Protocol on the application of certain aspects of Article 14 of the Treaty to the United Kingdom and Ireland, both countries were given the right to make arrangements concerning the movement of persons between their territories (Common Travel Area). Under these arrangements, citizens of the Republic of Ireland living in the United Kingdom and citizens of the United Kingdom living in the Republic of Ireland were granted the right to move freely within their countries on the basis of their EU citizenship. 
In view of these conditions, the border between the Republic of Ireland and Northern Ireland, with both countries being members of the European Union, was devoid of any barrier characteristics.

The United Kingdom's exit from the European Union significantly changes the nature of the border as it will no longer be an internal border of the European Union, but an external one. This has led to concerns about the restoration of the so-called "hard border" and the destabilization of the peace process on the island. Consequently, the question of the future of this border is the most important issue for the negotiation process. The main subject of the dispute is not so much to guarantee the free movement of people within the whole island, as this seems to be the easiest thing to do, but to establish new regulations concerning customs rates and the rules concerning the movement of goods, capital or services. The status quo would mean that Northern Ireland remains in the customs union and the EU Single Market. Once Brexit has taken place, the UK will no longer be able to operate within these structures. This means significant changes in the regulation of trade relations between the Republic of Ireland and Northern Ireland.

\section{BREXIT AND CHANGES OF THE BORDER FUNCTION}

Therefore, the negotiations between the European Union and the United Kingdom focus, on the one hand, on amounts due from the United Kingdom, and on the other hand, on citizens' rights and the status of the Northern Irish border. In both the European Union and the United Kingdom, the question has arisen about the consequences of this new situation for British citizens living and working in the European Union, as well as the consequences for European Union citizens living and working in Great Britain. The key issue for the Republic of Ireland is to restore the control and customs functions at the border with Northern Ireland, which may significantly restrict the free movement of goods, labour, capital and services (Wordin, 2018).

Therefore, with the start of the negotiations between the United Kingdom and the European Union, the issue of the border between the Republic of Ireland and Northern Ireland has become a leading theme. The question of how the United Kingdom will deal in this context with the movement of people and goods across borders has arisen. In addition, further doubts concern the implications of these talks and what this means for the citizens of the Republic of Ireland who live in and move to Northern Ireland. It should be noted here that, given the turbulent history between the Republic of Ireland and Ulster, ensuring their peaceful coexistence should be a particular priority.

The wide range of freedoms associated with the European Union was of mutual benefit to both countries and their citizens. The membership of the United Kingdom and the Republic of Ireland in the European Union, combined with the Good Friday Agreement, not only contributed to ending the conflict between Ireland and Northern Ireland, but in practice also resulted in the "invisible" border between the two countries (Barret, Bergin, Fitzgerald, 2015). Moreover, the consent of both countries to the establishment of the Common Travel Area provided their citizens with a high degree of migration freedom in moving from one country to another. 
In view of the United Kingdom's withdrawal from the European Union, there is a growing concern about the reintroduction of passport controls and visa requirements for people crossing the existing border. It was assumed that the reintroduction of passport controls at the border with Northern Ireland would not only restrict the freedom of movement between the Republic of Ireland and the United Kingdom, but also result in the immediate abolition of the right of Irish citizens to work freely in the United Kingdom (Barret, Bergin, Fitzgerald, 2015). In this situation, in the negotiations concerning this issue, each side (including the European Union) should strive to maintain the "invisible border," which in turn would make it possible to avoid the introduction of passport controls (O’Carrol, 2017). Perhaps this would be possible with regard to local border traffic.

There is also a significant concern that Brexit, by restricting population movements, particularly in the Republic of Ireland and Northern Ireland, could lead to a growth in unemployment and affect wage rates. In the light of labour market surveys conducted in the United Kingdom and the Republic of Ireland, the conclusion is that these markets are closely interrelated, which means that a lack of workers' freedom of movement from the Republic of Ireland to the United Kingdom will have a significant impact on the unemployment rate, as well as the increase of labour supply in the Irish labour market, which in turn will influence the wage rates in Ireland (Barret, Bergin, Fitzgerald, 2015). At the same time, a rise in unemployment, coupled with a fall in wages, may have a significant impact on a decrease in domestic demand in Ireland, which in turn may affect the country's economic situation.

The reactivation of the economic and customs-related function of the Irish-British border as a barrier may also have consequences for its impact on the level of foreign direct investment from the United Kingdom in the Republic of Ireland. When the United Kingdom had unlimited access to the European Union's Single Market, this significantly helped the movement of foreign direct investment. It should be noted here that FDI resources in the UK are the largest in Europe and the second largest in the world, after the United States (Barret, Bergin, Fitzgerald, 2015). As long as the UK was a member of the European Union, its membership was a key factor in attracting FDI to the country, both from the European Union and from third countries. There is therefore a concern that Brexit may have a negative impact on the British FDI. Indeed, many companies that have invested in the UK may reconsider their decisions on where to locate their investments if the UK leaves the Union. At present, these companies' decisions are only withheld by the transition period, which is to last until 2022, and they are waiting for the final determination of trade relations between the UK and the Union. However, with the uncertainty about the outcome of the negotiation process between the European Union and the United Kingdom, investors' incertitude, anxiety and a sense of investment risk concerning the future access to European Union markets are growing. Such a situation could, in turn, be advantageous for the Republic of Ireland, to which investments from the United Kingdom could flow as a result of relocation (Morgenroth, 2015).

However, this raises the question whether, in the long run, a potential large inflow of foreign investment into the Republic of Ireland will not result in a significant dependence of its economy on foreign capital. Furthermore, it should be noted that the 
closeness of the Republic of Ireland and the United Kingdom has so far resulted in investment firms in both countries benefiting from access to both markets. It also raises concerns whether the exit of the United Kingdom from the European Union will not affect the outflow of investment from the Republic of Ireland or reduce the positive effect of investment flows from the United Kingdom to the Republic of Ireland.

There is also a concern that, in conditions where the economies of the United Kingdom and the Republic of Ireland can be treated as a system of connected vessels, the loss of foreign direct investment in the United Kingdom due to Brexit may result in losses for the Republic of Ireland. This is closely linked to the interconnections between the two markets. The United Kingdom market is an outlet for products manufactured in the Republic of Ireland. Thus, if there is an outflow of foreign investment from the United Kingdom and as a result of this process there is a decrease in gross domestic product and economic growth, then this situation will imply a decrease in economic growth in the Republic of Ireland. And even if an increase in investment inflows into the Republic of Ireland can be expected, they may not compensate for potential losses.

Actual changes in the area of foreign investment will depend to a large extent on the UK's access to the European Union's Single Market, and therefore reflect the real nature of the Irish-British border in economic and customs terms. The UK's negotiated access to the EU market will determine the perception of this border as a barrier, while changes in the flow of foreign investment may constitute its real dimension.

Restoring the barrier dimension of the economic and customs-related function of the border may also have consequences for the common commercial policy. Both countries are major trading partners because of their immediate proximity. With both of them being members of the European Union, the movement of goods and persons across borders was completely unrestricted. This is important for trade volumes. It is estimated that, under the previous conditions, this arrangement increased the British trade volume by over 20\% (Mac Coille, 2016). In addition, $13 \%$ of Irish exports were to the UK market (Mac Coille, 2016). Therefore, the prospect of changes in trade and customs policy in the context of Brexit may adversely affect mutual trade.

This challenge is particularly strongly determined by the outcome of the negotiations between the UK and the European Union and will undoubtedly affect the scale of the border's impact on trade volumes between Ireland and the UK. The question arises here how a potential decline in mutual trade will affect a decline in gross domestic product. It is estimated that the new economic and customs-related dimension of the border may cause the UK to lose from $1.1 \%$ to $3.1 \%$ of its real GDP, but given the reduction in labour productivity, this decline may even reach from $6.3 \%$ to $9.5 \%$ of GDP (Wordin, 2018: 10). Such a situation could significantly reduce the GDP per capita of Ireland by from $0.8 \%$ to $2.7 \%$ due to trade losses in relations with the UK (Wordin, 2018: 10). It is also estimated that Brexit will contribute to a reduction in trade between Ireland and the UK of over 20\% (Wordin, 2018: 10). The final size of these losses will depend on solutions adopted in the negotiations. However, there is no doubt that the UK's exit from the European Union, regardless of the arrangements concerning their trade relations, will have a negative impact on trade volumes in the Republic of Ireland.

Of particular importance for the emergence of a barrier dimension of the economic and customs-related function of the border will be those negotiation outcomes which 
will determine the UK's access to the EU single market. It should be stressed at this point that in the event that the UK is not granted access to this market as a result of the negotiations, it will be forced to adopt the World Trade Organization rules, among which the Highest Preference Clause is an important element (Mac Coille, 2016). This, in turn, would mean that the UK would have to face the EU's customs policy. This could lead to higher import prices. Due to Ireland's trade links with the United Kingdom, the country may experience difficulties related to the need to reduce the volume of goods imported from the United Kingdom and the need to replace them with goods imported from other EU countries or produced on the domestic market. Consequently, the existence of customs tariffs at the border of the United Kingdom will cause significant difficulties for the Republic of Ireland, since the restriction of exports to the United Kingdom market, if such exports are not adequately redirected to other European Union countries, will be a serious problem for Ireland. This is because the Irish economy, which is largely export-oriented, has too small an internal market to absorb this production. Under these conditions, with the prospect of tariffs as well as other barriers to trade, the activation of the economic and customs-related function of the border as a barrier may cause the Republic of Ireland to experience significant losses as a consequence of Brexit.

Therefore, it can be assumed that the character of the Irish-British border may also result in the emergence of barriers other than customs tariffs. As this border will become the external border of the European Union, goods moving between the two countries may be subject to new customs inspections on both sides of the border, as required by the European Union law. When the UK is no longer part of the European Union, for example physical inspections of goods may appear at the border, concerning norms, documentation, standards, labelling requirements or sanitary and veterinary regulations. It is estimated that increased documentation and standards requirements as well as associated border downtime may raise transaction costs from 2 to even $24 \%$, while the total cost of obtaining a certificate of origin of goods may amount to more than 450 euros per shipment (Smart Border 2.0, 2017: 17). Border controls can also extend the time of trucks clearance from 30 to 60 minutes and passenger cars from 10 to 20 minutes per car (Smart Border 2.0, 2017: 17).

All these regulations, considered in the context of Brexit, which give a barrier dimension to the border, may result in increasingly higher costs of handling border traffic with regard to the movement of goods, which may undoubtedly affect the prospect of the countries' mutual trade.

The sector particularly vulnerable to the consequences of these changes is agriculture. It is this sector of the economy that will be most likely to experience what the Irish-British border will be when its economic and customs-related function has acquired the barrier dimension. This border will be covered by the regulations that will make agricultural products encounter customs, tariff and non-tariff instruments. In $2016,40 \%$ of Irish agricultural exports and $60 \%$ of processed food exports went to the British market (Donnelly, 2017). This market accounts for $49 \%$ of beef, $78 \%$ of game, $22 \%$ of dairy products and $86 \%$ of fruit and vegetables, of all Irish agricultural exports (Donnelly, 2017). The emergence of tariffs, duties and other customs policy instruments in this area would make the export of these goods to the UK market more ex- 
pensive and, moreover, these products would be treated on an equal footing with those from other countries, which could lower prices and make Irish exports less profitable.

\section{POTENTIAL SOLUTION MODELS}

The Brexit perspective therefore implies the need to find a formula that would define a model for linking the British economy to the European Union economies and, on the other hand, the real dimension of the Irish-British border, in terms of the economic and customs-related function.

Potential solutions in this area make it possible to refer to three existing models: the Norwegian model, the Swiss model, and the World Trade Organization model.

The Norwegian model concerns the special status that this country enjoys in the European Union without being its full member. The main link between Norway and the European Union is the Agreement on the European Economic Area, which allows Norway and other countries of this structure to participate in the European Union market. Moreover, Norway is in the Schengen area. Thus, in accordance with the Norwegian model, in the relations between the United Kingdom and the European Union (including the Republic of Ireland), the four freedoms of economic exchange would continue to apply: the freedom of movement of goods, services, persons and capital. Furthermore, the agreement adopted within this model would allow the United Kingdom, in exchange for a financial contribution, to have access to EU programmes concerning social policy, research, culture, education, environment and transport (Henley, 2016). This solution would also allow people to move freely across the border with Northern Ireland.

The Norwegian model, through access to the EU Single Market, could significantly reduce projected costs and losses of the UK as a consequence of Brexit, including those in the area of trade and FDI (Henley, 2016). The UK's continued access to the EU market could also favourably influence trade relations with Ireland, reducing potential losses ensuing from the new dimension of the border's economic and customsrelated function. This solution could be thought to reduce the losses of the agricultural sector in Ireland, for which exports to the UK market are of key importance. It can also be concluded that such a model would establish British-Irish relations in a way that is the closest to EU solutions.

Though the Swiss model is similar to the Norwegian one, it has its own specificities and requirements. The border between the European Union and Switzerland does not constitute a significant barrier hindering or preventing cooperation. Despite the fact that Switzerland is not a member of the European Economic Area (EEA), it belongs to the Schengen Area and has concluded seven sectoral agreements with the EU, limiting the negative effects of its remaining outside this structure. These agreements concern the following:

- the freedom of movement of persons,

- air transport liberalisation,

- road transport liberalisation,

- cooperation in the area of agriculture,

- cooperation in the field of public procurement, 
- mutual recognition of technical requirements for products,

- scientific and technical cooperation (Trzcielińska-Polus, 2010: 182).

Agreements in these areas were signed on 21 June 1999 and entered into force on 1 June 2002 (Trzcielińska-Polus, 2010: 182). It should be noted that the scope of cooperation between the European Union and Switzerland has been continuously extended, but not to include the free movement of services. Thanks to bilateral regulations, Switzerland decided to take over certain aspects of the European Union legislation in exchange for access to the Single Market.

The example of Switzerland could be a model solution for the UK. It could be advantageous as it ensures the free movement of persons, mutual recognition of technical requirements for products, cooperation in the field of public procurement, agriculture, air and road transport. The problem is the lack of freedom to trade in services, which could restrict trade and investment flows to the UK. Therefore, this model may generate additional costs and create barriers to mutual trade. The resulting losses may also affect trade relations with Ireland.

The Swiss model has its strengths and weaknesses. Unlike the Norwegian model, it does not guarantee all four freedoms, but it would exempt the UK from adopting some EU regulations. It is therefore more sovereign. As far as the Irish-British border is concerned, the freedom of movement of people is retained, while the economic and customs-related function is strengthened.

The model following the standards of the World Trade Organization (WTO) is, in the Brexit perspective, the most sovereign but also the most risky for the British economy. In this model, the United Kingdom would be a country applying WTO trade rules, which emphasize bilateral trade agreements based on the Most Favoured Nation clause (Bergin, Garcia-Rodriquez, Morgenroth, 2017: 305-316).

It should be noted at this point that this solution would mean that for the European Union, the United Kingdom would be a so-called third country for which access to the European single market would be associated with numerous barriers and restrictions. This, in turn, will result in negative consequences for the economy of the Republic of Ireland. In this model, the Irish-British border is a completely external border of the European Union, with full consequences for the free movement of people and goods. Acting solely within the WTO framework, the United Kingdom could impose trade barriers on Irish products, which in turn would affect their export to the British market. This would be particularly important for the agricultural sector. Ireland, recognizing the higher costs of maintaining trade in agricultural products with the UK, would most likely be forced to negotiate new trade terms or to seek new markets. It should be stressed, however, that in this model it would be possible to search for various alternative solutions which in the modern world could relate to the current relations between the USA and Canada (despite membership in the North American Free Trade Agreement (NAFTA), these countries have concluded bilateral agreements on the movement of goods and persons across the border) or to the relations between Australia and New Zealand.

In the event that the UK opted for bilateral trade agreements with the Republic of Ireland under the above option, one of the proposed solutions would be the Smart Border 2.0 concept, introducing a technical solution for the functioning of the Irish-British border (Smart Border 2.0, 2017: 37-43). It assumes maintaining an open border 
for free movement within the Common Travel Area, by creating free lanes at border crossing points, allowing for free movement of citizens. Moreover, according to the proposed solutions, through the so-called extended licenses and thanks to cooperation between the legislative bodies of the United Kingdom and the Republic of Ireland, it would be possible to create such legal standards that would enable faster correlation of the legal provisions of both countries. In this context, the assumption is that all border formalities, including border controls, could be reduced in the case of both exporters and importers who are known to the authorities of both countries due to their past business practices. For this to be possible, both countries would have to agree to technological investments in the field of customs clearance technology, including, for instance, unmanned automatic controls (without stopping at the border) which would allow the identification of vehicles and passengers from both countries.

At present, we can witness the formal withdrawal of the United Kingdom of Great Britain and Northern Ireland from the European Union, with a transitional period lasting until 2022 during which negotiations between the two parties will take place. This time allows the creation of different scenarios for the relationship between the United Kingdom of Great Britain and the Union. Each of these scenarios will simultaneously determine the character of the border between the Republic of Ireland and Northern Ireland. Changes in the border functions will affect both the movement of people and the trade policy. Flows of foreign investment will significantly determine the functioning of the British and Irish economies in this respect. The scale of this impact, both negative and positive, will undoubtedly depend on the results of negotiations, whose "final product" will be a definition of the legal and economic framework for the functioning of the UK as a Non-member State.

The state of negotiations and the determination of the British side since the referendum of 2016 have made Brexit a reality. This means that the Irish-British border will have to function under a new formula. In fact, the only clear aspect of the new dimension of this border is that it will have to take into account the functioning of both countries in the Common Travel Area. It is therefore necessary to create conditions to ensure that restrictions connected with crossing the border are as light as possible, both for citizens and economic entities.

The Smart Border concept seems to be an interesting proposal which, in the current conditions of technological development, could mitigate the effect of such an outcome of negotiations that would make the border between the Republic of Ireland and Ireland a considerable barrier.

\section{REFERENCES}

Agreement on the withdrawal of the United Kingdom of Great Britain and Northern Ireland from the European Union and the European Atomic Energy Community (2020), OJ EU L. 29/7 of 31 January. 
Anderson M. (2004), Frontiers. Territory and State Formation in the Modern World, Oxford.

Balawajder G. (2017), Instytucja granic zewnętrznych Unii Europejskiej a zapewnienie bezpieczeństwa państw członkowskich $w$ warunkach współczesnego kryzysu migracyjnego, "Pogranicze. Polish Borderlands Studies", Vol. 5, No. 3.

Balawajder G. (2010), Zanik czy nowe funkcje granicy w Unii Europejskiej, in: Ewolucja instytucji granicy we współczesnej Europie, (ed.) S. M. Grochalski, Opole.

Barret A., Bergin A., Fitzgerald J., Lambert D., Mc.Coy D., Morgenroth E. W., Siedschlag I., Stadnicka Z. (2015), Scoping the Possible Economic Implications of Brexit on Ireland, "Economic and Social Researcher Institute", No. 48 (November).

Bergin A., Garcia-Rodriquez A., Morgenroth E. W., Smith D. (2017), Modeling the Medium - to Long-Term Potential Macroeconomic Impact of Brexit on Ireland, "The Economic and Social Review", No. 3 (Autumn).

Common Travel Area (2019), Home Office, Publisher for Home Office Staff on 28 February,

Crawley J. (2019), Granica urojona, "Polityka", No. 9.

Donnelly M. (2017), UK remains Ireland's top trading partner, despite 6pc drop in exports, "Farm Ireland", July 27.

Grochalski S. M. (2010), Wprowadzenie do problematyki instytucji granicy państwa instytucji. Refleksje obywatela Unii Europejskiej, in: Ewolucja instytucji granicy we współczesnej Europie, (ed.) S. M. Grochalski, Opole.

Henley J. (2016), Can the UK Adopt the Norway Model's as its Brexit Solution, "The Guardian", December 1.

Inter Trade Ireland (2017), Potential Impact of WTO Tariffs on Cross Border Trade, June.

Ireland in brief (2020), Published by Department of Foreign Affairs, Dublin.

Mac Coille C. (2016), The economic impact of Brexit on Ireland, "Dairy Research", March 31.

Morgenroth E. W. (2015), Economic Consequences for Ireland, The Institute of International and European Affairs, Dublin.

O' Carrol L. (2017), How does the Irish Border Affect the Brexit Talks, "The Guardian”, June 21.

Smart Border 2.0 Avoiding a hard border on the island of Ireland for Customs control and the free movements of persons (2017), "Constitutional Affairs", Policy Department for Citizens' Rights and Constitutional Affairs, Directorate General for Internal Policies of the Union, PE 596.828 - November.

The Ireland Act of 2 June 1949 (2019), www.legislation.gov.uk (16.05.2020).

The text of the 1921 English - Irish Treaty (2019), https://treaties.un.org./doc/Publication/UNTS/ LON (3.05.2020).

Trzcielińska-Polus A. (2010), Zmiany funkcji oraz zasięgu granic ugrupowań integracyjnych w Europie (ze szczególnym uwzględnieniem granic Unii Europejskiej), in: Ewolucja instytucji granicy we współczesnej Europie, (ed.) S. M. Grochalski, Opole.

Whyte J. H. (1991), Interpreting Northern Ireland, Clementon Press, Oxford.

Whyte J. H. (1983), The Permeability of the UK-Irish Border. A Preliminary Reconnaissance, "Administration", No. 31.

Wojtaszek-Mik E., Mik C. (2005), Dorobek Schengen, in: Unia Europejska. Wspólnota Europejska. Zbiór dokumentów, (eds.) E. Wojtaszek-Mik, C. Mik, Zakamycze.

Wordin A. (2018), Ireland and the Economic Impact of Brexit, "Pepperdine Policy Review", Vol. 10, 3 February. 


\begin{abstract}
The subject of the paper is reflections on the consequences of Brexit for the functioning of the border between Ireland and Northern Ireland. The author explains what this border means when the United Kingdom is no longer a member of the European Union, and thus the border may be a barrier to the free movement of people, goods, capital and services. At the same time, it is stressed that the exit of the United Kingdom from the European Union will have a significant impact on the change of the function of this border, which from then on is no longer an internal border of the Union.

The aim of the paper is therefore to analyse the consequences of this change, with a simultaneous indication of different models of the UK's functioning with relation to the European Union and their impact on the British-Irish relations, especially with regard to the various dimensions of the border as a barrier.

The article presents various scenarios of solutions that will determine their mutual relations as a result of negotiations between the European Union and Great Britain, especially with regard to access to the single European market, which in turn will be influenced by the border between Ireland and Northern Ireland in the scope of the free movement of people, goods, capital and services. The author used the system analysis method and the comparative method.

The author puts forward the thesis that if the negotiations cause a fairly strong loosening of relations between the UK and the European Union, to mitigate the consequences of such a situation for the Irish-British relations, it will be necessary to find and develop bilateral solutions that will facilitate border crossing. The Smart Border 2.0 concept can constitute such a solution.
\end{abstract}

Keywords: Brexit, border between the Republic of Ireland and Northern Ireland, Common Travel Area, European union, internal Union border, external border of the Union, border functions

\title{
GRANICA BRYTYJSKO-IRLANDZKA W KONTEKŚCIE BREXITU
}

\section{STRESZCZENIE}

Przedmiot artykułu stanowią rozważania dotyczące konsekwencji Brexitu dla funkcjonowania granicy pomiędzy Irlandią a Irlandią Północną. Autor wyjaśnia, czym jest ta granica w warunkach, kiedy Wielka Brytania nie jest już członkiem Unii Europejskiej, a więc przebieg tej granicy może stanowić barierę dla swobodnego przepływu osób, towarów, kapitału i usług. Artykuł jednocześnie podkreśla, że wyjście Wielkiej Brytanii z Unii Europejskiej będzie miało istotny wpływ na zmianę funkcji tej granicy, która od tej chwili nie będzie już wewnętrzną, lecz zewnętrzną granicą Unii.

Celem artykułu jest zatem analiza konsekwencji tej zmiany z równoczesnym wskazaniem różnych modeli funkcjonowania Wielkiej Brytanii względem Unii Europejskiej oraz ich wpływu na relacje brytyjsko - irlandzkie, szczególnie w odniesieniu do różnych wymiarów przejawiania się granicy, jako bariery. Autor zastosował metodę analizy systemowej i metodę porównawczą.

Artykuł wskazuje na różne możliwe scenariusze rozwiązań, jakie w wyniku negocjacji pomiędzy Unią Europejską a Wielką Brytanią określą ich wzajemne relacje, szczególnie w odniesieniu do dostępu do jednolitego rynku europejskiego, czego z kolei implikacją będzie oddziaływanie granicy pomiędzy Irlandią a Irlandią Północną w zakresie swobody przepływu osób, towarów, kapitału i usług. 
Autor stawia tezę, że w przypadku, jeśli negocjacje spowodują dość mocne rozluźnienie związków Wielkiej Brytanii z Unią Europejską, to dla złagodzenia skutków tej sytuacji dla relacji irlandzko - brytyjskich istnieje konieczność znalezienia i wypracowania bilateralnych rozwiązań, które ułatwią przekraczanie granicy. Takim rozwiązaniem może być koncepcja Smart Border 2.0.

Słowa kluczowe: Brexit, granica pomiędzy Republiką Irlandii a Irlandią Północną, Wspólny Obszar Podróży, Unia Europejska, granica wewnętrzna Unii, granica zewnętrzna Unii, funkcje granicy 